\title{
PENYELESAIAN SENGKETA HAK CIPTA MENURUT UNDANG-UNDANG NO.19 TAHUN 2002 TENTANG HAK CIPTA
}

\author{
Oleh : Jatmiko Winarno, SH, MH
}

\begin{abstract}
Abstrak
Praktek perdagangan musik dan lagu yang melanggar hak cipta dituangkan dalam bentuk VCD dan DVD di lingkungan jalan marak dilakukan. Hal ini tentunya mengundang permasalahan dalam konteks pelanggaran hak cipta dan membutuhkan langkah-langkah hukum untuk meminimalisir hal tersebut. Sejalan dengan itu, telah dilakukan penelitian yang berhubungan dengan hal tersebut dengan menggunakan metode penelitian hukum empirik. Hasilnya, terdapat sejumlah permasalahan atas pelanggaran hak cipta baik secara perdata dan pidana. Langkah penyelesaian yang dilaksanakan berupa sosialisasi dan penegakan hukum.
\end{abstract}

\section{Kata kunci : Hak Cipta, Undang - undang Nomor 19 Tahun 2002.}

\section{Pendahuluan}

Suatu hasil karya kreatif yang akan memperkaya kehidupan manusia akan dapat menghabiskan waktu bertahun-tahun untuk mengembangkannya. Apabila si pencipta karyakarya tersebut tidak diakui sebagai pencipta atau tidak dihargai, karya-karya tersebut mungkin tidak akan pernah diciptakan sama sekali.

Hak Atas Kekayaan Intelektual (selanjutnya disebut HAKI) merupakan hak atas kekayaan yang timbul atau lahir dari kemampuan intelektual manusia. HAKI memang menjadikan karya-karya yang timbul atau lahir karena adanya kemampuan intelektual manusia yang harus dilindungi. Kemampuan intelektual manusia dihasilkan oleh manusia melalui daya, rasa, dan karsanya yang diwujudkan dengan karya-karya intelektual. Karya-karya intelektual juga dilahirkan menjadi bernilai, apalagi dengan manfaat ekonomi yang melekat sehingga akan menumbuhkan konsep kekayaan terhadap karyakarya intelektual.

UUHC membawa kemajuan baru dalam perlindungan hak tersebut, yang meliputi perlindungan terhadap buku, program komputer, pamflet, sampul karya tulis yang diterbitkan, dan semua hasil karya tulis lain, ceramah, kuliah, pidato, lagu atau musik dengan atau tanpa teks, drama, tari, koreografi, pewayangan dan pantomim, seni rupa dalam segala bentuk, arsitektur, peta, seni batik, fotografi, sinematografi, terjemahan, tafsir, saduran, bunga rampai, data base dan karya lain dari hasil pengalihwujudan.

Secara spesifik, Undang-undang ini memuat beberapa ketentuan baru, antara lain:
1. Database merupakan salah satu ciptaan yang dilindungi;

2. Penggunaan alat apapun baik melalui kabel maupun tanpa kabel, termasuk media internet untuk pemutaran produk-produk cakram optik (optical disc) melalui media radio, media audio visual dan/ atau sarana telekomunikasi;

3. Penyelesaian sengketa oleh pengadilan niaga, arbitrase atau alternatif penyelesaian sengketa;

4. Penetapan sementara pengadilan untuk mencegah kerugian lebih besar bagi pemegang hak ;

5. Batas waktu proses perkara perdata di bidang hak cipta dan hak terkait baik di pengadilan niaga maupun di Mahkamah Agung ;

6. Pencantuman hak informasi manejemen elektronik dan sarana kontrol teknologi;

7. Pencantuman mekanisme pengawasan dan perlindungan terhadap produk-produk yang menggunakan sarana berteknologi tinggi;

8. Ancaman pidana atas pelanggaran Hak Terkait;

9. Ancaman pidana dan denda minimal;

10. Ancaman pidana tetap terhadap perbanyakan penggunaan program komputer untuk kepentingan komersial secara tidak sah dan melawan hukum.

\section{Metode Penelitian}

1. Type Penelitian 
Sesuai dengan judul dan materi yang di bahas maka penelitian ini adalah penelitian yuridis normatif, metode penelitian hukum normatif adalah suatu prosedur penelitian ilmiah untuk menemukan kebenaran berdasarkan logika keilmuan hukum dari sisi normatif. Oleh karena itu penelitian hukum ini di fokuskan untuk mengkaji penelitian hukum tentang upaya hukum penentuan dan penyelesaian sengketa hak ciptaan.

\section{Pendekatan Masalah}

Oleh karena type penelitian yang di gunakan adalah type penelitian yuridis normatif, maka pendekatan masalah yang digunakan adalah pendekatan perundangundangan (Statute Approach), pendekatan tersebut melakukan pengkajian pengaturan perundang-undangan yang berhubungan dengan pokok permasalahan. Selain itu juga digunakan pendekatan analisis (Analitical Approach), Pendekatan ini maksudnya menganalisa tentang penentuan dan penyelesaian sengketa hak ciptaan.

3. Bahan Hukum

a. Bahan Hukum Primer

Merupakan bahan hukum yang bersifat autoritatif artinya mempunyai otoritas bahan hukum primer terdiri dari perundang-undangan.

b. Bahan Hukum Sekunder

Berupa semua publikasi tentang hukum yang bukan merupakan dokumendokumen resmi, yaitu berupa buku teks, kamus-kamus hukum, jurnal-jurnal hukum dasar,komentar-komentar atas putusan pengadilan.

4. Prosedur Pengumpulan Bahan Bahan

Baik bahan primer maupun bahan sekunder dikumpulkan berdasarkan topik permasalahanyang telah dirumuskan dan diklarifikasi menurut sumber dan hirarkinya untuk di kaji secara komprehensif.

5. Pengolahan dan Analisis Bahan Hukum
Adapun bahan yang diperoleh dalam penelitian studi kepustakaan aturan perundang-undangan, yang penulis uraikan dan dihubungkan sedemikian rupa, sehingga di sajikan dalam penulisan yang lebih sistematis guna menjawab perumusan masalah yang dirumuskan. Cara pengolahan data dilakukan secara deduktif yakni menarik kesimpulan dari suatu permasalahan yang bersifat umum terhadap permasalahan kongkrit yang dihadapi.

\section{Manfaat Penelitian}

Penulis berharap bahwa kegiatan penelitian dalam penulisan hukum ini akan bermanfaat bagi penulis maupun orang lain.Adapun manfaat yang dapat di peroleh dari penulisan hukum ini antara lain :

1. Manfaat Teoritis

a. Penelitian ini diharapkan dapat memberikan manfaat pada pengembangan ilmu pengetahuan di bidang ilmu hukum pada umumnya dan dalam rana hukum perdata khususnya.

b. Hasil penelitian ini diharapkan dapat memperkaya referensi dan literatur dalam dunia kepustakaan tentang upaya hukum terhadap penentuan dan penyelesaian sengketa hak ciptaan menurut undang-undang no.19 tahun 2002 tentang hak cipta.

c. Hasil penelitian ini dapat digunakan sebagai bahan untuk membuat suatu keputusan tentang penentuan dan penyelesaian sengketa hak ciptaan menurut undang-undang no.19 tahun 2002 tentang hak cipta.

2. Manfaat Praktis

a. Menjadi wahana bagi penulis untuk mengembangkan penalaran membentuk pola pikir ilmiah sekaligus untuk mengetahui kemampuan penulis dalam menerapkan ilmu yang diperoleh.

b. Untuk memberikan jawaban atas permasalahan yang di teliti.

\section{Pembahasan}




\section{Penentuan Pencipta dan Pemegang Hak Cipta}

Konsep perlindungan hak cipta adalah melindungi pencipta dan hasil ciptanya, dimana dalam UUHC terdapat perbedaan antara pencipta dan pemegang hak cipta. Begitu pula dengan lagu atau musik, dimana didalamnya terdapat unsur pencipta dan pemegang hak cipta.

Pencipta musik atau lagu adalah seseorang atau beberapa orang secara bersamasama yang atas inspirasinya lahir suatu ciptaan musik atau lagu berdasarkan kemampuan pikiran, imajinasi, kecekatan, keterampilan atau keahlian yang dituangkan dalam bentuk yang khas dan bersifat pribadi, yang dalam istilah lain dikenal sebagai komposer

Menurut Pasal 1 huruf 2 UUHC, disebut sebagai pencipta apabila "Seorang atau beberapa orang secara bersama-sama yang atas inspirasinya melahirkan suatu ciptaan berdasarkan kemampuan pikiran, imajinasi, kecekatan, keterampilan atau keahlian yang dituangkan kedalam bentuk yang khas dan bersifat pribadi."

Sedangkan pemegang hak cipta menurut pasal 1 huruf 4 adalah pencipta sebagai pemilik hak cipta atau pihak yang menerima hak tersebut dari pencipta atau pihak lain yang menerima hak tersebut.

Berdasarkan pengertian diatas pencipta dapat sekaligus sebagai pemegang hak cipta dalam hal hak cipta tersebut tidak dialihkan kepada pihak lain, akan tetapi pemegang hak cipta belum tentu ia sebagai pencipta karena dapat dimungkinkan pemegang hak cipta menerima pengalihan hak dari pencipta atau membeli hak tersebut dari pencipta.

Hak cipta sebagai benda bergerak yang immaterial merupakan obyek hukum perdata (dalam hukum kebendaan) walaupun sesungguhnya hak cipta merupakan obyek tidak berwujud ( intiangible ), sehingga pada gilirannya hak cipta dapat dimilki sebagai mana layaknya hak kebendaan ( tangible property) lainnya.
Hak cipta adalah kekayaan personal maka hak cipta dapat disamakan dengan bentuk kekayaan yang lain, yakni dapat dialihkan. Secara khusus pengaturan mengenai pengalihan hak dan hukum hak cipta diatur dalam Pasal 3 ayat (1) UUHC, bahwa hak cipta dianggap sebagai benda bergerak maka hak ciptanya dapat dipindah tangankan, di lisensikan, dialihkan, dijual-belikan oleh pemilik atas pemegang haknya.

\section{Proses Penyelesaian Sengketa Hak Cipta}

Dalam UUHC telah diatur perlindungan hukum terhadap pemegang hak cipta atas lagu atau musik. Perlindungan hukum yang dimaksud diberikan kepada pemegang hak cipta musik atau lagu atas perbuatan pihak lain yang dengan tanpa hak mengumumkan atau memperbanyak ciptaan musik atau lagu. Perbuatan pengumuman ini sendiri adalah pembacaan, pameran, penjualan, pengedaran atau penyebaran suatu ciptaan dengan menggunakan alat apapun, termasuk media internet atau melakukan dengan cara apa pun sehingga suatu ciptaan dapat dibaca, didengar atau dilihat orang lain.

Pemegang hak cipta dilindungi baik secara pidana maupun perdata. Dari sisi pidana, perlindungan hukum bagi pemegang hak cipta (musik atau lagu) diatur dalam Pasal 72 Ayat (1) UUHC yang menentukan bahwa barang siapa dengan sengaja dan tanpa hak melakukan perbuatan sebagaimana dimaksud dalam Pasal 2 Ayat (1) atau Pasal 49 Ayat (1) dan Ayat (2) dipidana dengan pidana penjara masing-masing paling singkat satu bulan dan/atau denda paling sedikit $\mathrm{Rp} 1.000 .000$,- atau pidana penjara paling lama 7 tahun dan/atau denda paling banyak $\operatorname{Rp} 5$ milliar. Selanjutnya dalam Ayat (2) ditentukan bahwa barang siapa dengan sengaja menyiarkan, memamerkan, mengedarkan atau menjual kepada umum suatu ciptaan atau barang hasil pelanggaran hak cipta atau hak terkait sebagaimana dimaksud pada Ayat (1) dipidana dengan pidana penjara paling lama 5 tahun dan/atau denda paling banyak Rp 500.000.000,-

$$
\text { Sedangkan Perlindungan }
$$

hukum dari sisi perdata tidak hanya dilakukan dengan gugatan melalui Pengadilan Niaga akan tetapi bisa diselesaikan melalui alternatif penyelesaian sengketa. Demi kepentingan bisnis dengan mengingat keuntungan yang diperoleh 
melalui penyelesaian sengketa di luar pengadilan, UUHC memungkinkan untuk menyelesaikan perselisihan di bidang hak cipta (khususnya lagu) melalui arbitrase dan sejumlah alternatif penyelesaian sengketa lainnya berdasarkan UUHC dimana alternatif penyelesaian sengketa lainnya tersebut antara lain adalah konsultasi, negosiasi, mediasi, konsiliasi, atau penilaian ahli.

\section{Kendala dalam penanganan tindak} pidana hak cipta yang terjadi

Hukum sebagai serangkaian norma yang memiliki ukuran pasti dan daya paksa dalam pelaksanaanya senantiasa berjalan berdampingan dalam kehidupan manusia. Hukum berfungsi melindungi dari kepentingan lain yang merugikan. Hukum mengidealkan satu keseimbangan dalam keteraturan antara hak dan kewajiban.

Secara perspektif Internasional Persetujuan tentang Aspek-aspek Hak Atas Kekayaan Intelektual (HAKI) yang terkait dengan perdagangan (agreement on Trade Related Aspects of Intellectual Property Rights;TRIPs) yang merupakan bagian yang tidak terpisahkan dari Persetujuan Pembentukan Organisai Perdagangan Dunia (Agreement Establising the World Trade Organisation) telah diratifikasi berdasarkan Udang-Undang Nomor 7 Tahun 1994. implikasinya, bahwa Indonesia harus melakukan harmonisasi dengan ketentuanketentuan yang ada didalamnya.

\section{Penutup}

A. Kesimpulan

Berdasarkan bab-bab tersebut diatas, maka penulis menyimpulkan sebagai berikut:

1. Hak Cipta merupakan salah satu bentuk dari hak atas kekayaan intelektual pada dasarnya telah mendapatkan perlindungan dari secara hukum baik melalui hukum nasional maupun hukum Internasional. Perlindungan terhadap hak cipta berfungsi untuk melindungi hakhak yang dimiliki oleh pencipta atas karya ciptaannya, hak cipta juga melindungi potensi pencipta karena eksistensi terhadap kemampuan yang dimiliki seorang pencipta untuk menciptakan suatu karya cipta dan karya ciptaannya tetap terjaga. Dengan adanya hak cipta seorang pencipta tetap memiliki semangat untuk menciptakan sesuatu karena ia merasa aman dan nyaman sehubungan dengan adanya perlindungan terhadap hak yang ia miliki sebagai seorang pencipta.

2. Penyelesaian sengketa yang diambil oleh pihak pertama dengan pihak kedua adalah alternatif penyelesaian sengketa dengan jenis negosiasi. Dimana dalam negosiasi ini pihak pertama menggunakan pengacaranya untuk mewakili mereka yang kemudian melakukan kesepakatan dengan pihak kedua. Hasil kesepakatan tersebut kemudian didaftarkan di pengadilan paling lama 30 hari sejak penandatanganan agar mempunyai kekuatan ekselutorial berdasarkan Pasal 6 ayat (7) UU No. 30 Tahun 1999. Hasil kesepakatan tersebut wajib segera dilaksanakan paling lambat 30 hari sejak didaftarkan dke pengadilan berdasarkan Pasal Pasal 6 ayat (8) UU No. 30 Tahun 1999.

\section{B. Saran}

1. Seharusnya kita berhati-hati apabila akan menyiarkan, mengedarkan ataupun menyanyikan lagu milik orang lain untuk tujuan komersil. Kita harus berpikir bahwa apa yang kita siarkan, edarkan atau nyanyikan adalah hak cipta orang lain yang tentunya bisa menimbulkan permasalahan dikemudian hari, seperti adanya tuntutan ganti rugi. Oleh karena itu apabila kita akan menyiarkan, mengedarkan atau menyanyikan lagu milik orang lain, kita harus terlebih dahulu meminta perizinan kepada pencipta maupun pemegang hak ciptanya.

2. Apabila memang terjadi perselisihan mengenai hak cipta hendaknya ditempuh jalur alternatif penyelesaian sengketa yang prosedurnya lebih mudah dan tidak mengeluarkan banyak biaya. 


\section{DAFTAR PUSTAKA}

Abdul Kadir Muhammad, Kajian Hukum Ekonomi Hak Intelektual, PT.Citra Aditya Bakti, Bandung 2001.

Bahan Bacaan Sujud Margono,Hukum Dan Perlindungan Hak Cipta, CV Novindo Pustaka Mandiri, Jakarta, 2003.

Djumhana dan R. Djubaedilah IV,Hak Milik Intelektual (sejarah, Teori, dan

Munir Fuady, Arbitrase Nasional (Alternatif Penyelesaian Sengketa ),PT. Citra Aditya Bakti, Bandung, 2000. Abdulkadir Muhammad, Kajian Hukum Ekonomi Hak Intelektual, PT.Citra Adtya Bakti, Bandung,2001.

OK. Saidin, Aspek Hukum Hak Kekayaan Intelektual,PT.Raja Grafindo Persada, Jakarta, 2001.

Prakteknya di Indonesia), Cetakan kedua, PT. Citra Aditya Bakti, Bandung, 2003,

Setiawan, Aneka Masalah Hukum dan Hukum Acara Perdata, Alumni Bandung, Bandung, 1992.

Sri Soemantri, Prospek dan Pelaksanaan Arbitrase di Indonesia,PT. Citra Aditya Bakti, Bandung, 2001.

Sudargo Gautama, Perkembangan Arbitrase Dagang Indonesia,Eresco, Bandung, 1989

Tim Penyusun Kamus Pustaka Pembinaan dan Pengembangan bahasa, kamus besar bahasa Indinesia, Balai Pustaka, Jakarta 1988.

Zae ,Berbisnis nada jangan sampai di penjara.www.inovasi.lipi.go.id/hki/news, 2003.

\section{PERUNDANG-UNDANGAN :}

Undang - undang Nomor 19 Tahun 2002 perubahan atas Undang-undang

Nomor 12 Tahun 1991 Tentang Hak Cipta.

Undang - undang Nomor 14 Tahun 2001 tentang Undang-Undang Nomor 13
Tahun 1997 Tentang Perubahan atas Undangundang Nomor 14 Tahun 1997 tentang Perubahan atas Undang-Undang Nomor 19 Tahun 1992 Tentang Merk.

Undang - undang Nomor 30 Tahun 2000 Tentang Rahasia Dagang.

Undang - Undang Nomor 31 Tahun 2000 Tentang Desain Industri.

Undang-Undang Nomor 32 Tahun 2000 Tentang Desain Tata Letak Sirkuit Terpadu. 